\title{
Sobre o Tratado de ateologia, de Michel 0nfray
}

\author{
About the Atheistmanifesto, by Michel 0nfray \\ Sobre el Tratado de ateología, de Michel Onfray
}

Luis Francisco Fianco Dias*

O fenômeno é cotidiano. Acontece conosco, com cada um de nós, acontece com todos os que estão à nossa volta. Na medida em que a realidade se torna insuportável demais, nos refugiamos em fantasias diversas que nos apaziguem ou pelo menos dotem de sentido o nosso sofrimento. Mas não condenamos sumariamente ao suplício, ao ostracismo ou à morte aqueles que não compartilham com os nossos próprios mecanismos psicológicos de fuga. Como, então, surgem e se estabelecem as religiões monoteístas, que fazem exatamente esse mesmo movimento, elevar à alucinação universal e obrigatória aquilo que foi um dia delírio de um só ou de um pequeno grupo? Quais são as consequências devastadoras desse modelo de pensamento, desse civilizacional procedimento agressivo, "evangelizador"? São essas justamente as questões abordadas em Traité d'athéologie pelo filósofo francês Michel Onfray, ${ }^{1}$ autor de diversos outros livros de sucesso tanto no cenário filosófico atual quanto fora dele, em função, certamente, tanto da maneira eloquente e contemporânea de expressão escrita quanto da temática prevalente de seus escritos, que abordam questões filosóficas atuais mantendo tanto a rigorosidade conceitual quanto a pertinência temática. Seus mais de cinquenta textos, que versam sobre uma grande gama de temas diversos, embora o leitor atento possa perceber uma ligação simpática entre eles, passando por assuntos como materialismo hedonista, afetividade e erotismo, subjetivação, tragicidade da existência, gastronomia filosófica, estão sempre retomando a necessidade da filosofia de se fazer presente

\footnotetext{
Doutor em Filosofia. Professor permanente do Programa de Pós-Graduação em Letras da Universidade de Passo Fundo, Brasil.
}

Recebido em 01/04/2016 - Aprovado em 01/09/2016 http://dx.doi.org/10.5335/hdtv.16n.2. 
na existência cotidiana dos seres humanos em vez de constituir uma linguagem técnica acessível exclusivamente a iniciados e eruditos. Com leituras e interpretações de Nietzsche, conserva desse a combatividade filosófica e a beleza de estilo. Por vezes seu desenvolvimento argumentativo leva a conclusões que podem escandalizar aos mais sensíveis, pois esta é a tarefa da (sua?) filosofia. Com seu Tratado de ateologia, com sua defesa de um ateísmo radical e sem concessões, não será diferente.

A obra se divide de forma bastante racional e esquemática, compondo quatro grandes partes que comportam, igualmente, subdivisões. Na primeira delas, Athéologie, o autor realiza uma investigação e reconstituição históricas do que se poderia chamar de ateísmo ao longo do progresso do pensamento humano. A segunda, Monothéismes, investiga o surgimento e as bases conceituais dos três monoteísmos ocidentais, o judaísmo, o cristianismo e o islamismo, para tentar entendê-los como fenômenos de ódio à vida e desprezo pelo mundo. Na sequência, apertando mais o cerco de sua crítica, Onfray prossegue, na terceira parte, Christianis$m e$, criticando especificamente o cristianismo, para, por fim, descrever os resultados nefastos desse modelo unívoco e imperativo de pensamento na existência prática e cotidiana, o que é feito na derradeira subdivisão, intitulada adequadamente de Théocratie.

Durante muitos séculos, ateísmo era uma condenação para uma vasta multiplicidade de posicionamentos diferentes, sendo que a maioria dos pensadores acusados de ateísmo não afirmaram literalmente, em momento algum, a inexistência da divindade, senão que, apenas, defendiam uma forma de interpretação da divindade que não era a adequada, a socialmente aceita pela ortodoxia vigente em suas diversas configurações, demonstrando o quanto o discurso religioso tem menos de elevação espiritual e mais de fundamentação das estruturas políticas e sociais. Tal posicionamento apenas dá mostras, e exemplos históricos abundam, de Spinoza a Salman Rushdie, daquilo que é a norma do monoteísmo, a intolerância contra todos os que ousaram defender a diversidade de pensamento. A promessa libertadora da morte de Deus, desespero da fiç̧ão de Dostoiévsky, tese maior da filosofia de Nietzsche, o primeiro ateu declarado, com cuja análise inicia-se a primeira seção do livro, restringe-se tristemente ao nome que lhe demos, promessa. Não se realiza, libertando a humanidade do jugo do sobrenatural, porque esse deus, fundamento ontológico transcendente, nem morreu nem está morrendo. Ele, que se alimenta da fraqueza humana e é criado pela incapacidade infantil da humanidade de responsabilizar-se por sua própria existência, de arcar com o ônus da realidade, ganha cada vez mais força no mundo contemporâneo, desvelando uma pulsão de morte, uma fraqueza de espírito, uma vontade de nada, uma fuga para o além-mundo como característica universal da subjetividade humana, salvo exceções isoladas. Dessa forma, o monoteísmo se alimenta da incapacidade de superação do niilismo e da fuga desesperada do sujeito novamente em direção ao mito. Os espíritos fortes, reforçados pela filosofia, que ousam se afirmar existencialmente, apesar da dor onipresente em um mundo vazio, 
são os acusados de ateísmo, pois a antítese que se coloca aqui é a da religião contra a filosofia, da obediência contra a reflexão, da passividade contra o conhecimento. Etimologicamente, Onfray chama a atenção para o alfa privativo que compõe o termo ateu, demonstrando que ele é uma criação do pensamento teísta, ou seja, interpretado como uma anomalia em oposição à normalidade, o que justifica, por sua negatividade, a sua eliminação tanto lógico-conceitual quanto fática, com perseguições, caçadas humanas, autos-de-fé, fogueiras de livros e de pessoas. $\mathrm{Na}$ história humana, a religião sempre foi a inimiga do conhecimento, pois esse, mitologicamente um presente da serpente do paraíso, sempre foi mundano, terreno, presente, sempre teve a intenção de expansão da vida, de potência, que é tudo o que um modelo de pensamento religioso, que se alimenta parasitariamente da fraqueza psicológica humana, tenta evitar. Como defesa de seus interesses, a religião ensina e cria o ser humano como falho, culpado, desprezível, incompleto, e o convence que apenas por meio da sua fusão com a divindade, da compra inflacionada de seu produto invisível ele poderá se sentir completo e feliz. Auxiliado pela filosofia de Nietzsche, o autor coloca o ateísmo como possibilidade de superação do niilismo, não apenas para a eliminação de deus, e sim para a criação de um mundo novo, outra sensibilidade, outra moral, para que uma era pós-cristã suceda à era cristã da mesma maneira que essa sucedeu ao paganismo da antiguidade, momento no qual os deuses do conhecimento dos filósofos foram suprimidos pelo deus infantil, irado, cruel e vingativo de Abraão, Jesus e Maomé. O que não se fez sem conflitos então e que igualmente não se dará sem conflito agora. Um ateísmo pós-moderno deve vir para substituir pelo hedonismo o monoteísmo religioso e o niilismo científico, criando vida onde agora há obediência e ódio, inaugurando uma relação com o outro que não seja de agressão potencial, e sim de oportunidade de intersubjetividade.

Na segunda parte, Monothéismes, retoma-se a argumentação da religião como manifestação da pulsão de morte em suas várias formas, principalmente do ódio de si mesmo representado pela condenação da materialidade em si, o corpo, o que obriga a criação de um espaço imaginário de um além fictício que será valorizado em detrimento da realidade do aqui presente, instalando a morte na terra para garantia da eternidade no céu, nesse paraíso a ser conquistado e que não passa, em suas variadas formas possíveis, de uma antítese perfeita de tudo o que é o mundo real, provando a sua relação com a fraqueza e o desespero, com o rancor e a impotência. Condenando a matéria, essa pulsão de morte religiosa condena igualmente o corpo, a sexualidade, o desejo, mas, criação masculina, condena sobretudo o feminino, as mulheres, e se baseia no inatacável mito da mulher que aceita um fruto de uma cobra falante (é normal, todas as cobras falavam, embora as de hoje sejam um pouco mais lacônicas) e com isso condena a humanidade inteira. Em sua fragilidade infantil, o masculino, longe de ser solar como gostaria, teme não tão secretamente o feminino na mulher, e a castração e impotência que esse medo gera o obrigam a criar mecanismos de domesticação da fêmea nas figuras da mãe 
e da esposa, a procriadora e a serva doméstica, mesmo que divinizadas e cultuadas, são uma jaula para o apaziguamento daquele feminino ameaçador e delicioso das divindades noturnas pagãs. Essa lógica cria nas religiões monoteístas a obsessão pela pureza, sustentada por uma dicotomia que opõe sempre o deus positivo e puro e bom à matéria negativa impura e corrompida à qual o feminino pertence simbolicamente. Além de tal enclausuramento, esse pensamento usa a castração como tentativa de supressão do desejo que expõe o sujeito à vivência plena, seja de fato, como o dos eunucos voluntários dos alvores do cristianismo, seja simbólico, como no ritual judaico da circuncisão, seja psicológico, como na renúncia cotidiana do desejo e com ele da vida da nossa cultura e todos os adoecimentos que ela ocasiona. Mas o ódio das religiões do amor ao próximo se estende também à condenação da inteligência e da ciência, pois elas é que propiciam reflexão e melhoria material das condições de vida, respectivamente cultura e civilização, e isso é muito problemático para quem sustenta seu discurso a partir da miséria material e espiritual. Mas isso não vale como condenação da erudição, pois a memória e a exegese passiva são estimuladas, na medida em que a memória é obediente e sagrada enquanto a reflexão é crítica e herética. As consequências práticas dessa condenação são tão terríveis que podemos ver a história ocidental como o desenvolvimento da luta entre o dogmatismo religioso e o progresso científico esclarecido e racional que aquele se propôs a entravar. Se dependesse do pensamento religioso monoteísta, não teríamos o heliocentrismo, a teoria da evolução, a psicanálise, a medicina, pois sem esses e diversos outros desenvolvimentos do engenho humano seria mais tranquilo manter a humanidade nas trevas do obscurantismo supersticioso, com a recompensa da felicidade eterna e bovina dos imbecis. Esse deus único que só se manifesta por interdições gera uma civilização fascinada pela morte e pela dor, pelo autoflagelo, para nos fazer esquecer que, se renunciarmos às ficções que apaziguam, nos sobra apenas a realidade em sua essência trágica. Podemos buscar dela consolação nas mais desvairadas fantasias, mas ao preço de nosso único bem, o mais precioso, a vida, esta mesma que estamos vivendo. Mais espanta ainda a fundamentação teórica dessas estruturas multimilenares de enfraquecimento da vida, Livros Sagrados, o que lhes permite identificarem-se simultaneamente como religiões do livro, nos raros momentos em que estão buscando similaridades entre si em vez de diferenças que justifiquem suas guerras ditas santas. Cada uma dessas religiões reivindica para si a posse do livro sagrado que contém, prontas e catalogadas, todas as verdades sobre a existência humana, desde as coisas mais prosaicas, que roupa se pode vestir, o que se pode comer, como apedrejar corretamente uma adúltera e sodomizar da maneira mais ortodoxa possível um camelo, até as mais rebuscadas inquietações humanas que, pelo bem da humanidade em geral e do humano em particular, deveriam ser sempre buscadas e recolocadas em vez de prontamente respondidas e passivamente obedecidas. Porém, da mesma maneira que a divindade tem a panificação como atividade de lazer, incorporando-se na hóstia, por exemplo, pa- 
rece também ter a produção escrita. Embora os textos sagrados sejam tidos como verdades reveladas, sua análise demonstra incongruências, contradições internas, evolução gramatical histórica separada por grandes lapsos temporais, narrativas inverossímeis (já citamos a cobra que fala?), revelando que se o escritor é divino, os editores e revisores são bem humanos e demasiadamente falíveis. Como instrumento de poder, esses livros não foram revelados, e sim produzidos, manipulados, forjados de acordo com interessas mundanos, temporalmente datados e facilmente identificáveis. Mesmo sua inconsistência pode ser intencional, pois diversas posições no mesmo texto podem servir de justificação igualmente à paz quanto à guerra, à tolerância e à perseguição, ao amor ao próximo e ao seu ostracismo.

A terceira parte do livro deixa para trás as análises dos monoteísmos judeu e muçulmano e retoma diretamente o monoteísmo que mais proximamente nos prejudica, o cristianismo. Destaca-se a figura de Paulo de Tarso que, com sua crise de cegueira histérica, inventa o cristianismo como o mecanismo político que será posteriormente tão bem aproveitado por Constantino, sedimentando o processo de afastamento da religião institucional da mensagem original de seu profeta mítico criador, pois não há evidência histórica nenhuma que suporte a existência fatual de um profeta chamado Jesus naquele contexto tempo-espacial que narram os Evangelhos. Dessa forma, a personagem fundadora foi inventada, utilizada como instrumento de ódio ao mundo, ao corpo e às mulheres, assuntos dos quais os Evangelhos não falam e que aparecerão apenas nas
Epístolas de Paulo, e então fixadas de forma institucional no Império Romano convertido, o primeiro totalitarismo teocrático da história europeia. O registro narrativo desse personagem mítico deve ser entendido, então, como as demais prosas da antiguidade, por seu caráter simbólico-metafórico, e não como fundamentação literal de ações e modelos de existência. Pleno de contradições e imprecisões históricas, os Evangelhos servem maliciosamente para desenrolar dessa interpretação fundamentalista que, então, permite um além-mundismo alimentado pela pulsão de morte, acompanhado de suas consequências de desprezo pela vida, submissão moral, sentimento de inferioridade e niilismo, ainda que o autor das epístolas nunca tenha lido dos Evangelhos uma única linha, pois morreu antes do primeiro deles ser escrito, nem mesmo conhecido Jesus pessoalmente, pois nasceu depois da data aceita como da morte desse. Segundo Onfray, o que Paulo de Tarso realiza é a projeção histérica no mundo de tudo aquilo do que ele mesmo padece, sua impotência se faz condenação da sexualidade, sua decepção consigo mesmo se faz ódio do mundo e amor aos humildes, seu fracasso social vira ódio à vida, sua fragilidade intelectual se transforma em condenação do conhecimento e rigor argumentativo dos filósofos da antiguidade, sua incapacidade para amar e ser amado se converte em ódio pelas mulheres. Obviamente, ele não é propriamente quem inventa essa postura, e sim aquele que a herda difusa no judaísmo, a fundamenta conceitualmente e cria as condições para que o islamismo continue esse mesmo processo com cada vez mais força. 
Por fim, temos o totalitarismo religioso. Após a conversão do Império, realizada, aliás, por meio um mecanismo bem pagão, o recurso à astrologia e do sincretismo descarado dos cultos já existentes, tanto da religião tradicional de Roma quanto das diversas seitas e cultos oriundas das províncias, se inventa definitivamente, canonicamente, o cristianismo. A habilidade político-estratégica de Constantino, inversamente proporcional a sua profundidade intelectual, lhe permite usar a religião dos escravos, antes banida, em proveito de uma continuidade de um estado já a caminho de sua dissolução. Com essa transformação, os perseguidos, mesmo dentro de sua pregação de amor ao próximo e justiça para todos, passaram a perseguidores, tanto de fato, com diversos casos de assassinatos de pagãos influentes e filósofos antigos, como de direito, com a promulgação de diversas leis que tornavam o ser pagão, paulatinamente, cada vez mais desvantajoso política e socialmente. O século XX conhece o procedimento, e com o uso, inclusive, dos mesmos argumentos fundamentadores dessa prática: o nazismo não era uma ideologia laica, fundamentava-se no deísmo, tinha ligações profundas com o Vaticano, admirava a religiosidade combativa do islamismo e sua teologia impiedosa. $\mathrm{O}$ monoteísmo, portanto, por sua relação com a pulsão de morte do ponto de vista teórico, termina por realizar, na prática, o contrário da proposta religiosa, ou seja, a intolerância, o imperialismo militarista, a perseguição, a chacina. Com raríssimas exceções particulares e pontuais, as religiões do amor ao próximo fazem do próximo uma vítima. Logo a ideologia religiosa se transforma em es- truturação de poder, em organização social e política, e se cristaliza em teocracia, que é o contrário perfeito da democracia que deveria fundamentar nossas relações em sociedade. Onfray sugere que se faz necessária, no momento presente, a emergência de uma laicidade pós-religiosa, em nosso contexto, pós-cristã, para que tenhamos efetivamente alguma mudança na estrutura do mundo. Isso passaria por uma mudança moral, certamente, mas também epistêmica, pois, enquanto a sociedade laica for apenas um reflexo racionalizado e desmistificado das mesmas doutrinas, valores morais e estruturas de opressão que ele herdou dos estados absolutista e teocrático que lhe precederam, nada terá mudado efetivamente. A moralidade e a incapacidade de uso de si do sujeito contemporâneo continuarão as mesmas do contexto religioso, apenas a sua fundamentação será realizada segundo outra doutrina, como a racionalista kantiana, por exemplo.

Essa obra, muito bem escrita e plena de argumentos fortes, demonstra a coragem intelectual de seu autor ao abordar de forma bastante direta uma problemática tão urgente no nosso mundo contemporâneo como as religiosidades monoteístas e sua sanha de exclusividade agressiva. É leitura obrigatória tanto para os que concordam com seu posicionamento, pela multiplicidade de argumentos e dados históricos fundamentados que o autor traz, quanto pelos que, na vivência de sua religiosidade, possam se sentir feridos por quilo que o texto está trazendo. Talvez até mesmo mais para esses do que para os primeiros, pois se, confrontados com todas essas críticas, transformassem a religião em algo completamente diferente 
do quadro que aqui pinta Michel Onfray com estilo ultrarrealista, estariam trazendo um grande benefício para a humanidade e, paradoxalmente, desmentindo um filósofo sincero que, talvez, adoraria estar errado.

\section{Nota}

1 Michel Onfray é doutor em filosofia e lecionou durante vinte anos em um liceu na França, do qual se demitiu em 2002 para fundar a Universidade Popular de Caen.

\section{Referências}

ONFRAY, Michel. Traité d'athéologie: physique de la métaphysique. Paris: Grasset, 2005. Le livre de poche. $315 \mathrm{p}$.

Tratado de ateologia. Tradução de Mônica Stahel. São Paulo: Martins Fontes, 2014. [Traité d'athéologie: Physique de la métaphysique]. 